Original Article

\title{
Design and optimization of an experimental maintenance system for yellow clam broodstock Amarilladesma mactroides (Reeve, 1854)
}

\author{
Desenvolvimento e otimização de um sistema de manutenção experimental para \\ reprodutores de marisco branco Amarilladesma mactroides (Reeve, 1854)
}

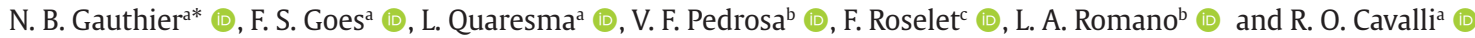 \\ a Universidade Federal do Rio Grande - FURG, Instituto de Oceanografia, Laboratório de Aquicultura de Bivalves, Rio Grande, RS, Brasil \\ ${ }^{\mathrm{b}}$ Universidade Federal do Rio Grande - FURG, Instituto de Oceanografia, Laboratório de Patologia e Imunologia de Organismos Aquáticos, Rio Grande, RS, Brasil \\ c Universidade Federal do Rio Grande - FURG, Instituto de Oceanografia, Laboratório de Produção de Microalgas, Rio Grande, RS, Brasil
}

\begin{abstract}
The yellow clam is a sand-burrowing bivalve that inhabits the dissipative beaches from southern Brazil to the north coast of Argentina. In the last decades, populations of this species have been impacted by mass mortality events, overfishing and other anthropogenic activities. The production of juveniles in captivity would allow feasibility studies to be carried out to restore the natural stock as well as the production in aquaculture systems. Given the scarcity of studies on the maintenance of this species in captivity, a culture system and a management protocol were developed and tested. Wild-caught clams (total length $\geq 50 \mathrm{~mm}$ ) were used in a series of 14 day-long trials. Survival was higher in clams that were allowed to bury into the sand. A permanent ink marker covered with a thin layer of a quick-hardening adhesive proved to be a reliable method to tag clams. The maintenance of yellow clams in this system resulted in high survival and growth, increases in the condition factor and oocyte diameter, and a relative advancement of gonadal development.
\end{abstract}

Keywords: aquaculture, bivalve, broodstock management, yellow clam.

\begin{abstract}
Resumo
O marisco branco é um bivalve de areia que habita as praias dissipativas do sul do Brasil até a costa norte da Argentina. Nas últimas décadas, as populações desta espécie têm sido afetadas por eventos de mortalidade maciça, sobrepesca e outras atividades antropogênicas. A produção de juvenis em cativeiro permitiria a realização de estudos de viabilidade para restaurar o estoque natural, assim como a produção em sistemas de aquicultura. Dada a escassez de estudos sobre a manutenção desta espécie em cativeiro, um sistema de cultivo e um protocolo de manejo foram desenvolvidos e testados. Mariscos branco selvagens (comprimento total $\geq 50 \mathrm{~mm}$ ) foram utilizados em uma série de ensaios de 14 dias de duração. A sobrevivência foi maior nos mariscos que podiam ser enterrados na areia. Um marcador de tinta permanente coberto com uma fina camada de adesivo de endurecimento rápido provou ser um método confiável para marcar os mariscos. A manutenção dos mariscos neste sistema resultou em alta sobrevivência e crescimento, aumento do fator de condição e do diâmetro do ovócito, e um relativo avanço do desenvolvimento gonadal.
\end{abstract}

Palavras-chave: aquicultura, bivalve, manejo dos reprodutores, marisco branco.

\section{Introduction}

The yellow clam Amarilladesma mactroides (Reeve, 1854 ) is naturally found in the intertidal zones of sandy beaches from southern Brazil to the north coast of Argentina (Bergonci and Thome, 2008; Herrmann et al., 2009; Carvalho et al., 2015). In these environments, it is usually the bivalve mollusc with the highest biomass (McLachlan, 2018). Due to the high abundance, A. mactroides has been harvested over practically its entire range of distribution to be used as bait for sport fishing or, more importantly, for human consumption (Coscarón, 1959; Defeo et al., 1989). Unfortunately, overfishing has caused many populations to collapse (Defeo et al., 1989; Herrmann et al., 2009). Also, mass mortality events have significantly affected populations (Santos et al., 2016; Vazquez et al., 2016).

As a result of lower abundances, Cledón and Nuñez (2010) and Santos et al. (2020) recommended that young specimens of the yellow clam should be produced in

*e-mail: nathy_byrro@hotmail.com

Received: September 3, 2020 - Accepted: December 15, 2020 
captivity, thereby allowing feasibility studies to be carried out to restore the population stock in the natural environment. The availability of hatchery-reared juveniles, commonly called "seeds", would also open the possibility of producing this species in extensive aquaculture systems or farming them integrated with existing fish or shrimp culture systems. In the last decades, aquaculture has been responsible for most of the world production of molluscs, which increased from 1 million tonnes in 1950 to 17.7 million in 2018 (FAO, 2020). However, a significant part of this production relies on the capture of juveniles in their natural environment (Helm et al., 2004; Wisjman et al., 2019). Hence, the control and manipulation of bivalve reproductive cycles and the consequent production of juveniles in the laboratory will result in a greater availability of bivalve seeds (Gosling, 2015). Therefore, this study aimed to develop an experimental culture system and management practices that allow the maintenance of yellow clam as a starting point for studies on reproduction under laboratory conditions. Additionally, a marking method has been validated for this species.

\section{Materials and Methods}

\subsection{Experimental system}

An oval tank filled with $500 \mathrm{~L}$ of filtered $(1 \mu \mathrm{m})$, chlorinated/dechlorinated seawater was used as a maintenance tank for the clams. A 1 HP chiller (Gelaqua, Águas Mornas, Brazil) was used to maintain the temperature at $20^{\circ} \mathrm{C}$. A submerged pump (Sarlo SB 2700; São Caetano do Sul, Brazil) kept the water circulating between the chiller and the maintenance tank $\left(2,740\right.$ L.h $\left.^{-1}\right)$. Two air stones were introduced into the tank.

As $A$. mactroides has the habit of remaining buried in a sandy sediment (Coscarón, 1959), it was necessary to develop an experimental unit (EU) that had a layer of sand to allow the clams to bury themselves. The EU was built with a $150 \mathrm{~mm}$ diameter weldable PVC pipe and coupling (Figure 1) and placed directly on the bottom of the tank. To retain the sand layer and allow water to pass through, a $200 \mu \mathrm{m}$ mesh was placed $10 \mathrm{~cm}$ from the bottom using the PVC coupling. The sand was obtained in the intertidal zone of Cassino beach, Rio Grande, RS, Brazil. It was thoroughly washed with tap water and sterilized with sodium hypochlorite at a concentration of $12 \mathrm{ppm}$ for $24 \mathrm{~h}$ before use. The chlorine was then removed using vitamin $C$ in a concentration of $0.03 \mathrm{~g} . \mathrm{L}^{-1}$. An airlift was attached to the side wall of the EU to pump water from the bottom of the tank and allow the permanent circulation of water through the sand layer in a top-down direction, commonly referred to as 'downwelling', performing the oxygenation of the sand layer. The lower portion of the PVC pipe had four circular holes that allowed the passage of water. Smaller holes were also made in the upper part of the pipe, specifically at the height of the tank's water line, to drain any excess water pumped by the airlift. This model had a total height of $40 \mathrm{~cm}$ and a useable volume of $7 \mathrm{~L}$.

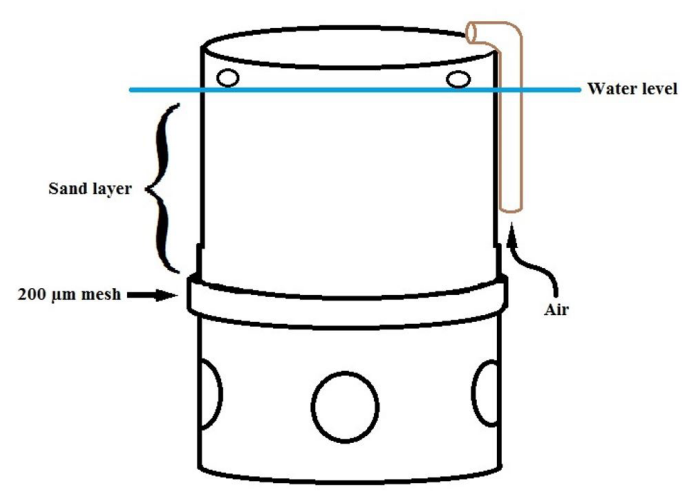

Figure 1. Experimental unit model built with a $150 \mathrm{~mm}$ PVC pipe and coupling, used in the maintenance of yellow clam (Amarilladesma mactroides) broodstock in the laboratory.

\subsection{Field campaigns and management of clams}

The collection of wild $A$. mactroides is registered in the National System of Genetic Resource Management and Associated Traditional Knowledge (SisGen) under no. AF0355A. Four campaigns were carried out. The first two were in December 2018 and February 2019 on the beach of Cassino ( $32^{\circ} 13^{\prime} 42.2^{\prime \prime S} 52^{\circ} 12^{\prime} 05.8^{\prime \prime} \mathrm{W}$ ), Rio Grande, RS. The other two were conducted in March and September 2019 on the beach of Mar Grosso (31 59 '20.0"S $\left.51^{\circ} 55^{\prime} 22.1^{\prime \prime} \mathrm{W}\right)$ in the municipality of São José do Norte, RS, Brazil. In all of them, water temperature and salinity were measured in situ with a thermometer and an optical refractometer, respectively (Table 1 ). Clams were collected from the intertidal zones with the help of flat shovels and, to minimize stress, they were transported to the laboratory by truck in thermal boxes with no water. The transport had a maximum duration of $90 \mathrm{~min}$.

Upon arrival at the laboratory, clams with broken valves, epibionts, parasites and siphons or feet with no movement were discarded. The selected individuals were blotted dry and the total length $(\mathrm{L})$, total height $(\mathrm{H})$ of the shell, and the wet (W) and dry weights (DW) were measured. L and $\mathrm{H}$ were measured with a manual caliper with a precision of $0.01 \mathrm{~mm}$ (Vonder, Curitiba, Brazil), and individuals with L less than $50 \mathrm{~mm}$ were also discarded. The wet weight was obtained with an electronic scale with a precision of $0.01 \mathrm{~g}$ (Marte Científica, São Paulo, Brazil). The initial and final DW were determined according to Helm et al. (2004). Additionally, the condition factor (CF) was determined at the beginning (CFi) and at the end (CFf) of each trial according to Froese (2006):

$$
C F=\frac{W}{L^{3}} \times 100
$$

where: $\mathrm{W}=$ total wet weight $(\mathrm{g})$ and $\mathrm{L}=$ total length $(\mathrm{cm})$.

After the measurements were taken, the clams were transferred to the EUs in the maintenance tank. According to the environmental conditions measured at the time of clam collection, the temperature and salinity of the water 
Table 1. Date (YYYY-MM-DD) and location of collection, temperature $\left({ }^{\circ} \mathrm{C}\right)$ and salinity at the time of sampling, and mean $( \pm$ SD) initial and final total length (Li and Lf; $\mathrm{mm}$ ), initial and final height (Hi and $\mathrm{Hf} ; \mathrm{mm}$ ), initial and final wet weight (Wi and Wf; g), initial and final dry weight (DWi and DWf; g), initial and final condition factor (CFi and CFf) and survival rate (\%) of yellow clam (Amarilladesma mactroides) collected at the beaches of Cassino, Rio Grande, RS and Mar Grosso, São José do Norte, RS, Brazil, and maintained in the laboratory for 14 days in the preliminary trial and in trials I, II and III ( $\mathrm{n}=40,60,60$ and 72, respectively).

\begin{tabular}{|c|c|c|c|c|}
\hline & Pre-trial 1 & Trial I & Trial II & Trial III \\
\hline Date & $2018-12-21$ & 2019-02-15 & 2019-03-14 & 2019-09-19 \\
\hline Location & Cassino & Cassino & Mar Grosso & Mar Grosso \\
\hline Temperature & 22.0 & 23.0 & 24.0 & 18.0 \\
\hline Salinity & 30 & 32 & 28 & 24 \\
\hline $\mathrm{Li}$ & $51.10 \pm 1.62$ & $53.10 \pm 1.93^{\mathrm{ca}}$ & $62.30 \pm 2.51^{\mathrm{Aa}}$ & $56.87 \pm 2.68^{\mathrm{Ba}}$ \\
\hline Lf & $54.30 \pm 1.90$ & $53.23 \pm 1.73^{\mathrm{Ca}}$ & $62.45 \pm 2.71^{\mathrm{Aa}}$ & $57.01 \pm 2.79^{\mathrm{Ba}}$ \\
\hline $\mathrm{Hi}$ & $29.10 \pm 1.90$ & $28.57 \pm 0.02^{\mathrm{cb}}$ & $33.25 \pm 0.02^{\mathrm{Aa}}$ & $30.27 \pm 0.03^{\text {Bb }}$ \\
\hline $\mathrm{Hf}$ & $31.20 \pm 0.80$ & $28.84 \pm 1.03^{\mathrm{Ca}}$ & $33.35 \pm 1.04^{\mathrm{Aa}}$ & $30.61 \pm 1.00^{\mathrm{Ba}}$ \\
\hline Wi & $11.36 \pm 1.62$ & $12.44 \pm 1.12^{\mathrm{ca}}$ & $19.77 \pm 1.14^{\mathrm{Ab}}$ & $13.74 \pm 1.19^{\mathrm{Bb}}$ \\
\hline Wf & $13.67 \pm 1.18$ & $12.56 \pm 1.44^{\mathrm{Ca}}$ & $21.31 \pm 3.02^{\mathrm{Aa}}$ & $16.37 \pm 2.71^{\mathrm{Ba}}$ \\
\hline DWi & n.d. & n.d. & $8.87 \pm 0.92^{\mathrm{A}}$ & $5.24 \pm 0.47^{\mathrm{B}}$ \\
\hline DWf & n.d. & $5.03 \pm 0.15^{c}$ & $7.81 \pm 0.13^{\mathrm{A}}$ & $6.05 \pm 0.17^{\mathrm{B}}$ \\
\hline CFi & n.d. & $8.34 \pm 0.66^{\mathrm{ABa}}$ & $8.36 \pm 0.63^{\mathrm{Ab}}$ & $7.97 \pm 0.76^{\mathrm{Cb}}$ \\
\hline $\mathrm{CFf}$ & n.d. & $8.31 \pm 0.58^{\mathrm{Ba}}$ & $8.73 \pm 0.87^{\mathrm{ABa}}$ & $8.86 \pm 0.86^{\text {Aa }}$ \\
\hline Survival & $100 / 16.6$ & 88.3 & 71.8 & 76.6 \\
\hline
\end{tabular}

n.d. = not determined. Uppercase letters indicate significant differences between trials, while lowercase letters show significant differences between initial and final parameters in the same trial.

were gradually adjusted to $20^{\circ} \mathrm{C}$ and $30-35$, respectively, being maintained in these ranges as much as possible.

The water quality was monitored during the experimental periods. The dissolved oxygen concentration, temperature, salinity and $\mathrm{pH}$ were measured daily at 08:00 AM with an OxyGuard oximeter (Farum, Denmark), a mercury thermometer, ATAGO manual refractometer (Tokyo, Japan) and a Mettler Toledo bench pH meter (Barueri, Brazil), respectively. The concentrations of total ammonia and nitrite were also checked daily, while the concentration of nitrate and alkalinity were checked once a week, according to UNESCO (1983), AOAC (1990) and APHA (1998), respectively.

\subsection{Preliminary trial 1: adaptation to the experimental system and management}

The adaptation of clams was assessed by means of the survival rate and by observing the consumption of microalgae and the occurrence of feces, and, at the end of the trial, by the presence of dark spots in the sediment, which could indicate low concentrations of dissolved oxygen. Clams selected from a batch collected at Cassino beach, Rio Grande, RS, Brazil (Table 1), were stocked in two EUs placed in the maintenance tank. Each EU received 5 clams, which positioned themselves vertically in relation to the bottom. Six individuals of similar size were kept directly on the bottom of the maintenance tank over the 14 days of the pre-trial duration. These clams had no access to the sandy sediment and, therefore, without the possibility of burying, they remained in a horizontal position in relation to the bottom of the tank.

An average concentration of $6.5 \times 10^{4}$ cells. $\mathrm{mL}^{-1}$ of the microalgae Isochrysis galbana and Chaetoceros muelleri was kept in the maintenance tank by daily counting with Neubauer chambers. Daily means $( \pm$ SD) of temperature, salinity and dissolved oxygen concentration were $21.9^{\circ} \mathrm{C}$ ( \pm 1.1$), 31.3( \pm 0.9)$ and $7.86( \pm 0.19){\mathrm{mg} . \mathrm{L}^{-1}}^{-1}$ respectively. Any dead clams were immediately removed from the system. The absence of movement of the feet and siphons was considered as mortality criteria. After 14 days, clams were dug up, measured ( $\mathrm{L}, \mathrm{H}$ and $\mathrm{W}$ ) and the sediment was observed for dark spots.

\subsection{Preliminary trial 2: validation of tagging methodology}

To individualize clams and thus make it possible to estimate growth during the maintenance period in the laboratory, different tagging methods, based on Lemarié et al. (2000) and Hartmann et al. (2016), were tested. As in the previous trial, clams were selected from a batch caught at Cassino beach, Rio Grande, Brazil (Table 1). The clam shells were initially marked with different inks (permanent ink marker for projectors - Pilot, São Paulo, Brazil; permanent ink marker for CD/DVD - Faber-Castell, São Paulo, Brazil; and red nail polish - Risqué, Goiânia, 
Brazil) and a thin layer of a quick-hardening adhesive on top (Araldite Hobby ${ }^{\circledR} 10$ min, resin-based epoxy, Tekbond, Brazil; or ScotchBond ${ }^{\circledR}$, cyanoacrilate-based instantaneous glue, 3M, Brazil) in combination or not. The use of numbered plastic labels glued to the shells with ScotchBond ${ }^{\circledR}$ or Araldite was also tested. In the case of the use of Araldite or ScotchBond ${ }^{\circledR}$, after the shells were marked with ink, the cover was applied and left for 10 min to dry before transferring the clams to the EU.

Seven clams were tagged and kept in each EU with no feeding. The water in the maintenance tank was completely renewed every day. After 2, 4, 7 and 10 days, clams were removed from the EU to check the integrity of the tags. In cases when the tag had disappeared or it was ineligible, a new type of tag was tested. In some cases, the same individual was used to test two different types of tagging.

\subsection{Validation of the maintenance system}

Three trials (named I, II and III), each with a duration of 14 days, were carried out to further validate the maintenance system. After capture, selection, measurement and tagging, the clams were transferred to ten EUs installed in the maintenance tank. In trials I and II, the stocking density was 6 clams per EU and the daily water renewal of the maintenance tank was $20 \%$, while in trial III, 7 to 8 individuals were stocked in the EUs and daily water renewal was $100 \%$. The environmental conditions, the monitoring of the water quality variables and the management routine were the same as previously described unless stated otherwise.

For trial I, two microalgae (I. galbana and C. muelleri, in the proportion of 70 and $30 \%$, respectively) were maintained in the maintenance tank at a concentration of $15 \times 10^{4}$ cells. $\mathrm{mL}^{-1}$. In trials II and III, C. muelleri was kept at a concentration of $10 \times 10^{4}$ cells. $\mathrm{mL}^{-1}$. In all trials, microalgae were offered in the exponential growth stage of the population. To maintain a constant availability of microalgae, the concentration was monitored twice a day and, if necessary, more microalgae were added to the maintenance tank to maintain the established density and proportion. The daily consumption of microalgae per clam (C; cells. $\mathrm{mL}^{-1}$.clam) was estimated using the following formula:

$$
C=\left(\frac{T C m+T C t}{n}\right)
$$

where: $\mathrm{TCm}=$ total microalgae consumed in the morning count $\left(\right.$ cells. $\left.\mathrm{mL}^{-1}\right), \mathrm{TCt}=$ total microalgae consumed in the afternoon count (cells. $\mathrm{mL}^{-1}$ ) and $n=$ number of live clams.

At the end of each trial, the clams were blotted dry and L, H, W and DW were measured, and based on this data, the CF was estimated as described previously.

\subsection{Histological assessment of gonads and analyses of hemocytes}

To identify sex and gonadal maturation stage, 5 clams at the beginning and 5 at the end of trials II and III were sampled for histological analysis. The animals were fixed in $20 \%$ saline formalin until processing. The tissues were cut and placed in labelled cassettes. The samples were processed in a Leica TP1020 automatic processor (Wetzlar, Germany) with inclusion in Paraplast. After embedding, the blocks of tissue were sectioned at $5 \mu$ with a Leica RM 2245 microtome (Wetzlar, Germany) and stained with hematoxylin-eosin. The histological slides were examined using the Zeiss Primo Star optical microscope (Oberkochen, Germany) equipped with an AxioVision 4.8.2 camera and software, and images were obtained. The gonads were classified according to Masello (1987) and Herrmann et al. (2009). Larger and smaller diameters of the oocytes (DM and $\mathrm{dm}$ ) were measured using the Image J software (National Institutes of Health, Bethesda, USA) and analyzed at the beginning and the end of the trials.

Additionally, the immunological condition of clams was estimated based on Santos et al. (2016). For this, the hemolymph samples were withdrawn by puncturing the pericardial cavity and smear slides were mounted, fixed in methanol for $10 \mathrm{~min}$ in a refrigerator and then stained with Giemsa for $20 \mathrm{~min}$. Observations of the feeding and behavior of clams were carried out at random intervals throughout the different trials

\subsection{Statistical analyses}

The data was tested for the necessary assumptions (Normality, independence and homoscedasticity) for the application of one-way analysis of variance (ANOVA). The analyses were verified using Levene and Shapiro-Wilk or Levene and Kolgomorov-Smirnov tests. When the assumptions were not met, the arcsine of the square root (x) or $\log (\mathrm{x})$ was performed. The occurrence of significant differences between trials was initially verified through post-hoc Tukey HSD (initial parameters) or unequal Tukey (final parameters). All statistical analyses were evaluated at a $\mathrm{p}<0.05$ significance level.

The comparisons of $\mathrm{Li}, \mathrm{Wi}, \mathrm{Hi}$ and $\mathrm{Hf}$, and the final CF between trials was verified using one-way ANOVA. The initial CF and the Lf and Wf were tested using the nonparametric ANOVA and Kruskal Wallis test. The DWi of individuals in trials II and III was compared using the t-Student test, while the DWf was compared by oneway ANOVA. Differences in survival between trials were assessed using the Chi-square test. The means of Li, Lf, Wi, Wf, Hi, Hf, CFi and CFf within trials were compared using the paired t-Student test. Oocyte larger and smaller diameters ( $\mathrm{DM}$ and $\mathrm{dm}$ ) between trials were analyzed using the t-Student test, while differences between DM or dm in the same trial were analyzed using one-way ANOVA.

\section{Results}

\subsection{Preliminary trial 1: adaptation to the experimental system}

The means $( \pm$ SD) of $\mathrm{L}, \mathrm{H}$ and $\mathrm{W}$ of clams at the beginning and at the end of preliminary trial 1 can be seen in Table 1. Judging by the need to add more microalgae to the maintenance tank daily, in addition to the visualization of feces being expelled through the holes in the sediment, the clams actively consumed microalgae. When clams 


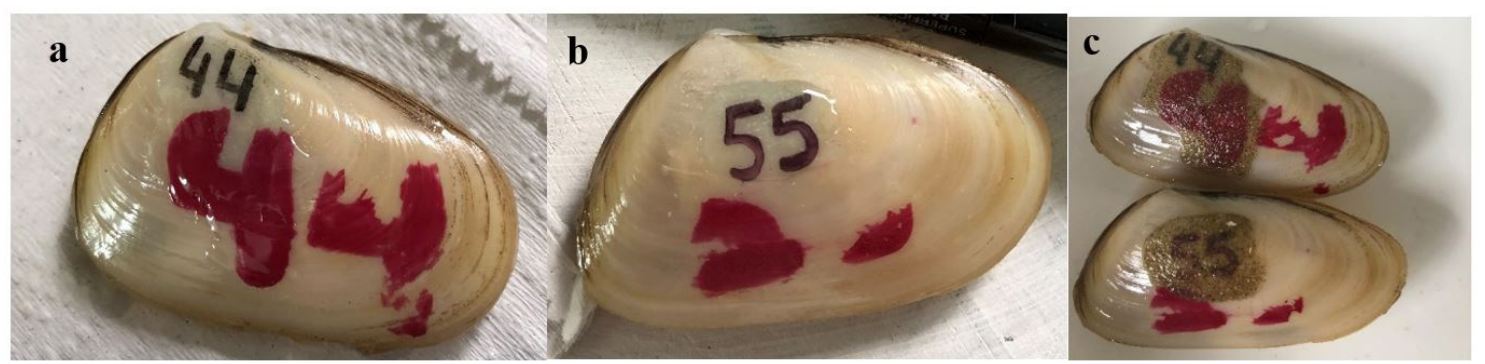

Figure 2. Yellow clams (Amarilladesma mactroides) numbered with a black permanent ink and a red nail polish covered with a bicomponent adhesive based on epoxy resin (Araldite) on the day that it was first marked ( $\mathrm{a}$ and $\mathrm{b}$ ) and after 10 days buried in the experimental maintenance system (c).

Table 2. Means $( \pm$ SD) of the water quality variables in three maintenance trials of the yellow clam Amarilladesma mactroides under laboratory conditions for 14 days.

\begin{tabular}{|c|c|c|c|}
\hline & Trial I & Trial II & Trial III \\
\hline Temperature $\left({ }^{\circ} \mathrm{C}\right)$ & $20.2 \pm 0.3$ & $20.0 \pm 0.2$ & $17.7 \pm 1.6$ \\
\hline Salinity & $30.7 \pm 0.7$ & $29.6 \pm 0.5$ & $23.7 \pm 1.3$ \\
\hline $\mathrm{pH}$ & $7.80 \pm 0.24$ & $7.71 \pm 0.26$ & $7.49 \pm 0.14$ \\
\hline Dissolved oxygen (mg.L $\mathrm{L}^{-1}$ ) & $7.35 \pm 0.11$ & $6.98 \pm 0.14$ & $7.77 \pm 0.62$ \\
\hline Total ammonia (mg.L $\mathrm{L}^{-1}$ ) & $0.04 \pm 0.02$ & $0.06 \pm 0.05$ & $0.05 \pm 0.02$ \\
\hline Nitrite (mg. $\left.\mathrm{L}^{-1}\right)$ & $0.08 \pm 0.05$ & $0.05 \pm 0.02$ & $0.01 \pm 0.01$ \\
\hline Nitrate (mg.L-1) & $3.16 \pm 0.30$ & $1.00 \pm 1.34$ & $2.79 \pm 2.20$ \\
\hline Alkalinity (mg. $\left.\mathrm{L}^{-1}\right)$ & $150.0 \pm 0.0$ & $160.0 \pm 10.0$ & $130.0 \pm 7.1$ \\
\hline
\end{tabular}

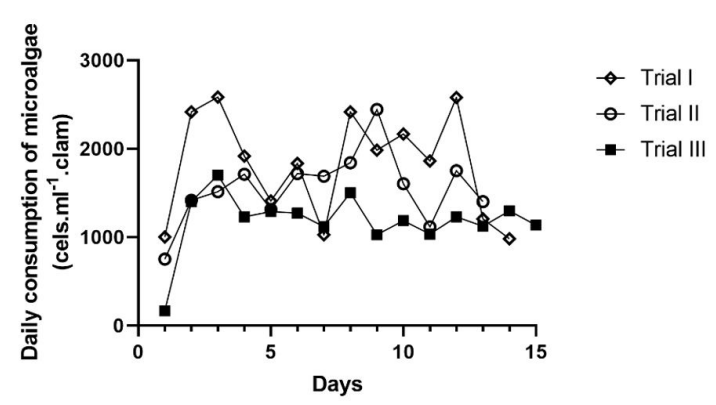

Figure 3. Mean daily consumption of microalgae (mixture of Isochrysis galbana and Chaetoceros muelleri on trial I or only C. muelleri on trial II and III) estimated for each individual (cells. $\mathrm{mL}^{-1}$. $\mathrm{clam}^{-1}$ ) of yellow clam (Amarilladesma mactroides) in trials I, II and III.

were dug up at the end of the trial, they were found at the bottom of the sand layer, close to the screen. After the water was drained from the EUs, the sand was still moist, with no odour or dark spots. The survival of clams kept in the EUs was $100 \%$, while only $16.7 \%$ of the clams dispersed at the bottom of the tank survived.

\subsection{Preliminary trial 2: validation of tagging methodology}

The tags combining a Pilot permanent ink marker for projectors with a layer of adhesive and also those with nail polish with a layer of adhesive were the ones that persisted the longest and showed the greatest visibility (Figure 2).

\subsection{Maintenance system validation trials}

The mean values of the water quality variables in the trials are presented in Table 2 . The mean temperature ranged from 17.7 to $20.2{ }^{\circ} \mathrm{C}$, while the salinity varied from 23.7 to 30.7. The mean concentrations of dissolved oxygen remained close to $7 \mathrm{mg} \cdot \mathrm{L}^{-1}$. The concentrations of total ammonia and nitrite were relatively stable and with values in the ranges of 0.04-0.06 and 0.01-0.08 mg. $\mathrm{L}^{-1}$, respectively. Nitrate concentrations remained below $3.5 \mathrm{mg} . \mathrm{L}^{-1}$. Mean alkalinity levels were above $130 \mathrm{mg} \cdot \mathrm{L}^{-1}$.

Although the estimate of the daily consumption of microalgae (Equation 2) differed between trials, it ranged from $1.0 \times 10^{3}$ cells. $\mathrm{mL}^{-1}$ to $3.0 \times 10^{3}$ cells. $\mathrm{mL}^{-1}$ per individual (Figure 3). In trial I, the consumption of the mixed diet (I. galbana and C. muelleri) ranged from $1.0 \times 10^{3}$ cells. $\mathrm{mL}^{-1}$ to $2.5 \times 10^{3}$ cells. $\mathrm{mL}^{-1}$ per individual per day. The daily consumption of $C$. muelleri per individual clam ranged from $0.2 \times 10^{3}$ to $1.7 \times 10^{3}$ cells. $\mathrm{mL}^{-1}$ in trial II, while in trial III it varied between $0.75 \times 10^{3}$ to $2.4 \times 10^{3}$ cells. $\mathrm{mL}^{-1}$.

Most biometric parameters showed significant differences between trials (Table 1). The clams in trial II had significantly higher Li, Lf, Hi, Hf, Wi, Wf, DWi and DWf than the individuals in the other trials, and these same parameters were significantly higher in the individuals in trial III compared to those in trial I. On the other hand, CFi (Equation 1) was significantly higher in clams from trial I and II ( $\mathrm{p}<0.0001$ and $\mathrm{H}=32.45)$, and clams in trial III had significantly higher CFf (Equation 1) ( $\mathrm{p}=0.0014$ and $\mathrm{F}=6.867$ ) than clams in trial I (Table 1 ). 
When biometric parameters were analyzed separately in each trial, significant increases in the height $(\mathrm{H})$ of the clams were observed in trial I (Table $1, p=0.000086$ ), wet weight $(\mathrm{W})$ in trial II $(\mathrm{p}=0.0002)$ and the wet weight $(\mathrm{W})$ and height $(\mathrm{H})$ of clams in trial III $(\mathrm{p}<0.0001, \mathrm{p}=0.0136$, respectively). Significant increases in the condition factor (CF) of clams from trials II and III (Equation 1 ) were also detected $(\mathrm{p}=0.0080, \mathrm{t}=2.843$ and $\mathrm{p}<0.0001, \mathrm{t}=8.114$, respectively).

Survival ranged from 71.8 to $88.3 \%$ (Table 1 ), and was not significantly different between trials $($ Chi-square $=2.9211$ and $\mathrm{p}=0.23$ ). As in preliminary trial I, no dark or odorous spots were observed in the sandy sediment at the end of any of the trials.

\subsection{Histological assessment of gonads and analyses of hemocytes}

Visual inspection of the clams showed no evidence of illness related to pathogens. The observation of the hemolymph slides indicated that the qualitative aspects of the different populations of hemocytes were within normal limits as defined for this species by Santos et al. (2016).

The histological analyses indicated that at the beginning of trial II the gonads of female clams were totally spawned, but after 14 days in captivity they were found to be partially spawned (Figure 4a). A large number of free, round oocytes in the lumen surrounded by connective tissue as well as some mature polygonal oocytes could be observed (Figure $4 \mathrm{~b}$ ). The male clams were initially in a stage of sexual rest, but, after 14 days, as spermatogonia and mature sperm were simultaneously present, the gonads were classified as partially spawned. In trial III, the gonads of initially sampled females were in an early ripe stage, with a thick follicular wall, presence of mature polygonal oocytes and some immature oocytes adhered to the follicular wall, and an increase of empty spaces in the lumen (Figure 4c). After 14 days in captivity, females had ripe gonads, with a large number of free polygonal oocytes in the lumen (Figure 4d). Male clams were also found to have early ripe gonads at the beginning of the
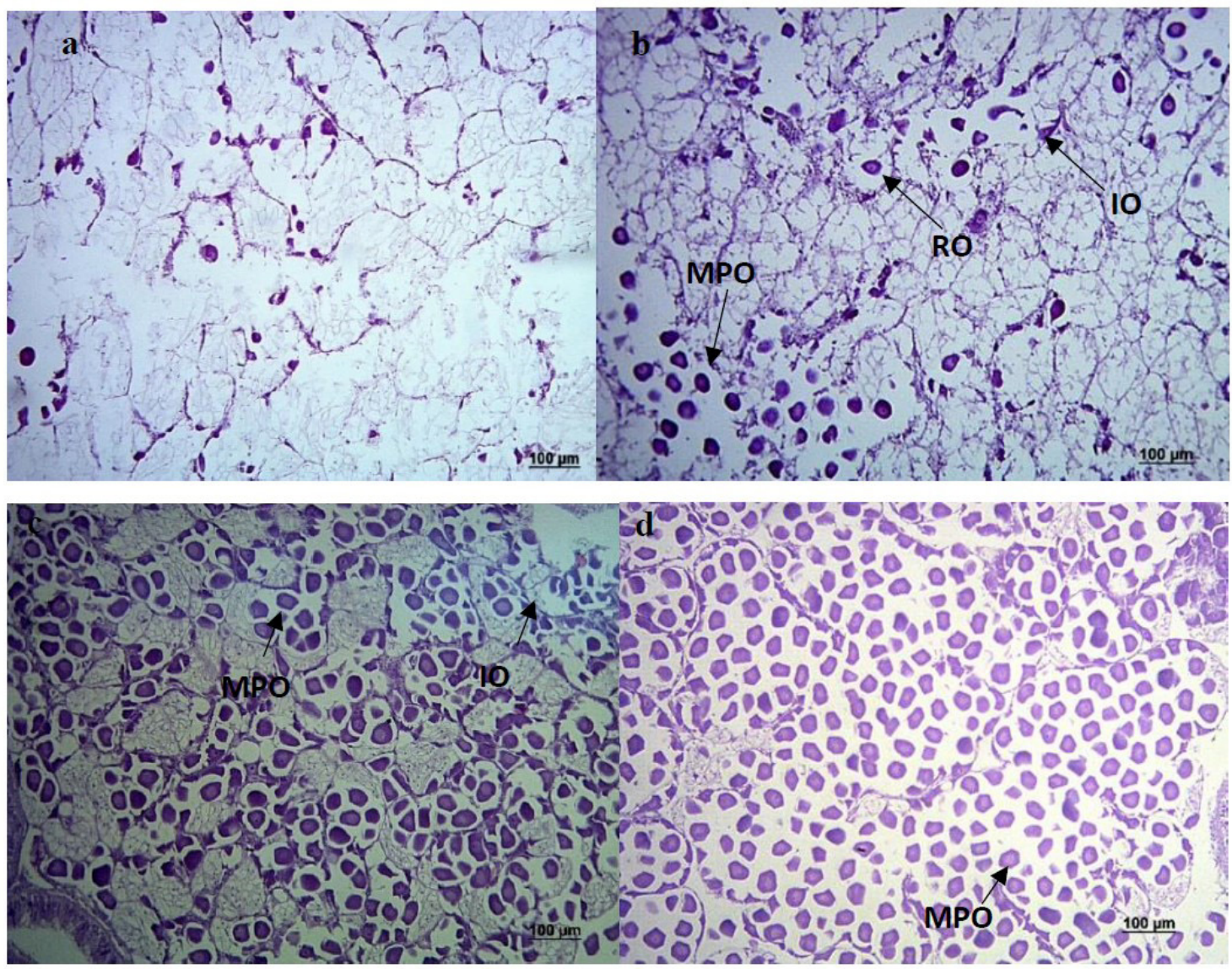

Figure 4. Histological sections of the tissues of yellow clam (Amarilladesma mactroides) sampled at the beginning and at the end of trial II (a, b) and trial III (c, d): (a) gonad of female clam with residual and immature oocytes in stage 6 (totally spawned) at the beginning of trial II; and (b) gonad of female clam in stage 5 (partially spawned) at the end of trial II, where it is possible to distinguish immature peduncular oocytes attached to the wall (IO), some free mature polygonal oocytes (MPO) and residual oocytes (RO); (c) gonad of female clam in stage 3 with immature (IO) and mature polygonal oocytes (MPO); (d) gonad of female clam stage 4, where several mature polygonal oocytes (MPO) may be observed. 
trial. Unfortunately, there were no males among the clams sampled at the end of trial III.

The larger (DM) and smaller (dm) diameter of the oocytes were significantly larger in trial III than in II (Table 3 ). In trial II, both DM and dm were significantly larger at the end of the experimental period. In trial III, the $\mathrm{dm}$ were significantly larger at the end of the experimental period. On the other hand, despite the tendency of an increased DM at the end of the experimental period, this difference was only numerical, with no significant differences being detected.

\section{Discussion}

Despite the ecological importance and economic interest in the yellow clam A. mactroides (Coscarón, 1959; Defeo et al., 1989; Bergonci and Thome, 2008), studies that focus on the production of seeds of this species, particularly those related to the maintenance and management of broodstock under laboratory conditions, are practically non-existent (Proverbio et al., 2019; Santos et al., 2020). Thus, the first steps in this study were to develop a system and evaluate management practices that offer adequate conditions for maintaining this species in captivity. Results of pre-trial 1 demonstrate that the survival of the clams that remained buried was $100 \%$, while only $16.7 \%$ of the clams dispersed in the bottom of the tank survived. This difference indicates the need to use a maintenance system that allows $A$. mactroides to remain buried in the sediment, which is somewhat in accordance with other studies on sand-burrowing clams. Proverbio et al. (2019) concluded that maintaining the yellow clam in an upright orientation significantly increased survival. Burying into the sediment and thus adopting their life position might facilitate some physiological processes such as filtration, feeding and respiration. Sassa et al. (2011) consider that the burrowing behaviour of bivalves in intertidal zones is a vital part of their main living activities and is as important as feeding and breeding. Spencer et al. (1991) state that the sediment is required by clams to maintain their position and keep their gills clean, while Helm et al. (2004) add that clams may feed more efficiently when kept in a suitable substrate. As a result, substrates are usually applied in the maintenance of adult clams in the laboratory (Helm et al., 2004; Ayerbe et al., 2018; Santos et al., 2020).

The water quality variables in the maintenance system remained relatively stable throughout the different experimental periods and, more importantly, were within the ranges recommended for bivalves (Helm et al., 2004) and specifically for A. mactroides (Carvalho et al., 2015;
Proverbio et al., 2019; Santos et al., 2020). Furthermore, at the end of all trials no dark or odorous spots were observed in the sandy sediment layer of any of the EUs, indicating that these were properly oxygenated. All this confirms that the environmental conditions were adequate and, therefore, that the maintenance system and the management practices applied here seemed to be suitable for $A$. mactroides. As a result, survival rates in the three trials were high, ranging from 71.8 to $88.3 \%$.

All yellow clams from trials I, II and III retained their tags after 14 days, confirming the feasibility of using either a permanent ink marker or nail polish covered by a thin layer of a quick-hardening adhesive. Thus, due to the greater ease of application, marking with a permanent marker and covering with a thin adhesive layer was considered the most appropriate method among those tested here. Further studies in our laboratory have shown that this methodology is also feasible for periods longer than 14 days (unpublished data). Proverbio et al. (2019) used numbered nylon tags as a tagging method for yellow clams. Although the tags remained intact after 6 days, clams were kept in aquaria with no substrate and hence the friction of tags with sand grains were not considered. The use of epoxy with tags for marking several species of freshwater mussels was recommended by Lemarié et al. (2000). These authors, however, found epoxy to be inferior to cyanoacrylate adhesives because the epoxy adhesive turned cloudy when immersed for less than $15 \mathrm{~min}$ and were easily abraded after drying. Although Hartmann et al. (2016) found similar results, they cited the risk of exposing bivalves to bisphenol A (BPA), an organic synthetic compound present in the epoxy resin. The effect of BPA can vary considerably among invertebrates, and molluscs appear to be quite sensitive to this compound (Canesi and Fabbri, 2015). Simas (2013) demonstrated that the exposure to low concentrations of BPA ( 5 and $20 \mu \mathrm{g} . \mathrm{L}^{-1}$ ) increased lipid damage in the digestive gland, gills and mantle of A. mactroides. Therefore, the use of cyanoacrylate seems to be a safer alternative to epoxy-based resin adhesive containing BPA in the tagging of A. mactroides.

It is well-known that the availability and quality of the algal diet provided to molluscs play a vital role in their growth and development (Utting and Millican, 1997; Helm et al., 2004; Gosling, 2015). In our trials, the supply of C. muelleri and/or I. galbana resulted in an estimated daily intake of 1.0 to $2.5 \times 10^{3}$ cell. $\mathrm{mL}^{-1}$ for each individual of $A$. mactroides. This somehow suggests that the feed management applied here was minimally adequate for the clams to survive and increase in size. Nevertheless, the provision of a diet containing two or more algal species

Table 3. Means $( \pm \mathrm{SD})$ of the largest $(\mathrm{DM})$ and smallest $(\mathrm{dm})$ diameters of the oocytes of yellow clams (Amarilladesma mactroides) at the beginning and at the end of 14 days of laboratory maintenance in trials II and III.

\begin{tabular}{ccccc}
\hline Trial & $\mathbf{D M}_{\mathbf{i}}$ & $\mathbf{D M}_{\mathbf{f}}$ & $\mathbf{d m}_{\mathbf{i}}$ & $\mathbf{d m}_{\mathbf{f}}$ \\
\hline II & $27.62 \pm 7.37^{\mathrm{Bb}}$ & $32.26 \pm 2.71^{\mathrm{Ba}}$ & $20.31 \pm 7.43^{\mathrm{Bb}}$ & $27.04 \pm 4.32^{\mathrm{Ba}}$ \\
III & $40.82 \pm 6.51^{\mathrm{Aa}}$ & $44.17 \pm 5.39^{\mathrm{Aa}}$ & $31.71 \pm 4.56^{\mathrm{Ab}}$ & $36.37 \pm 3.84^{\mathrm{Aa}}$ \\
\hline
\end{tabular}

Uppercase letters indicate significant differences between trials (Student t-test), while lowercase letters indicate significant differences between initial and final DM or dm in the same trial (one-way ANOVA). 
may further improve performance (Utting and Millican, 1997; Helm et al., 2004; Gosling 2015).

A thin layer of biofilm was visualized on top of the sandy sediment, particularly from the $6-7^{\text {th }}$ experimental day onwards. The formation of the biofilm is possibly a result of the settling of microalgae, feces and other organic wastes that served as a substrate to the establishment of a microbial community. Despite the high environmental quality in the maintenance system, an increase in the daily water renewal rate could affect the survival of clams as it would decrease the biofilm formed in the sand layer, thus reducing the possibility of pathogen proliferation. On the other hand, the presence of biofilm may be positive, since it may have a role on the decrease of the toxic nitrogen compounds through nitrification and, at the same time, it may serve as a food supplement (Skilleter and Peterson, 1994). In this regard, Defeo and Scarabino (1990) presented the hypothesis that, although being a suspension feeder, in situations of low oxygen levels and water recirculation, A. mactroides would consume organic debris present in the sediment using its inhaling siphon that reach to the surface. This alternative feeding behavior was also observed here. However, as the concentrations of dissolved oxygen in our trials were high (above $6.5 \mathrm{mg} . \mathrm{L}^{-1}$ ), it is possible that, contrary to what was suggested by Defeo and Scarabino (1990), low oxygen levels may not trigger this feeding behavior. The relatively small circulation of water associated with the availability of the biofilm on the sediment may be more important determinants of the detritivorous feeding strategy. Additional work into the feeding strategies of A. mactroides is needed to determine the importance and the processes involved in obtaining supplementary food from the sediment.

Growth in bivalves is often expressed as an increase in body size (Bayne and Worrall, 1980). Although our trials were relatively short (14 days), estimates of growth were positive in all of them. The daily means of length increase in trials I, II and III were estimated at $0.01-0.03 \mathrm{~mm}$, $0.02-0.04 \mathrm{~mm}$ and $0.02 \mathrm{~mm}$, respectively. In the wild, the growth of $A$. mactroides decreases with age, with two to three-year-old individuals growing between 0.03-0.05 and 0.01-0.02 mm.day ${ }^{-1}$, respectively (Cappezani et al., 1971). Therefore, the growth of yellow clams in this study is in line with the estimates presented by Cappezani et al. (1971) for wild animals.

The condition factor (CF) refers to the relationship between weight and length of the clams and thus describes the condition of the individuals' well-being. CF values can be influenced by sex, type and availability of food, reproductive stage and reproductive performance (Kumar et al., 2018). There are relatively few studies evaluating the CF of molluscs (Ferreri, 2014; Sousa et al., 2017) and an even smaller fraction covering bivalves (Sharma et al., 2005; Kumar et al., 2018). In this study, the CFi reflected the condition of the clams collected in the environment with clams from trial I and II having higher CFi (8.34 and 8.36) than those from trial III (7.97). Despite this small difference between trials, $\mathrm{CF}$ values greater than or equal to 1 show that clams were not under stress related to food shortages or the period of natural reproduction (Sharma et al., 2005; Kumar et al., 2018). Interestingly, there were significant increases over time in the $\mathrm{CF}$ of clams from trials II and III. According to Aldrich and Crowley (1986), increases in CF are a good indicator for food reserve accumulation for gonadal development in bivalves. This is in line with our results, which had a significant increase in oocyte diameter as well as advanced stages of gonadal development observed for females from trials II and III, and males in trial II at the end of the experimental period.

In conclusion, an experimental system and management practices for the maintenance of the yellow clam in captivity were developed and tested with relative success. The maintenance of yellow clams in the laboratory for 14 days promoted high survival and growth, but also an increase in condition factor, oocyte diameter and a relative advancement in terms of gonadal development. Whether this maintenance system and management practices will provide an adequate environment for the successful reproduction of $A$. mactroides held under laboratory conditions is an area of ongoing research.

\section{Acknowledgements}

Thanks to CNPq for the for the provision of study grants to N.B. Gauthier and F.S. Goes. L. Quaresma acknowledges a study grant from FAPERGS. V.F. Pedrosa and F. Roselet are postdoctoral fellows of PNPD/CAPES. L.A. Romano and R.O. Cavalli are research fellows of CNPq.

\section{References}

ALDRICH, J.C. and CROWLEY, M., 1986. Condition and variability in Mytilus edulis (L.) from different habitats in Ireland. Aquaculture, vol. 52, no. 4, pp. 273-286. http://dx.doi.org/10.1016/00448486(86)90370-4.

AMERICAN PUBLIC HEALTH ASSOCIATION - APHA. American Water Works Association and Water Environmental Federation, 1998. Standard methods for the examination of water and wastewater. 20th ed. Washington: APHA.

ASSOCIATION OF OFFICIAL ANALYTICAL CHEMIST - AOAC, 1990. Official methods of analysis. 15th ed. Washington: AOAC, $90 \mathrm{p}$.

AYERBE, R., ZEVALLOS, S., CASTAÑEDA, V., LOPE, F., BENDITA, H. and SANZ, Y., 2018. Manual: cultivo de la macha Mesodesma donacium (Lamarck, 1818) em la région Moquega [online]. El Callao: Instituto del Mar del Perú, vol. 45, no. 2, pp. 242-262. Available from: http://biblioimarpe.imarpe.gob.pe/handle/123456789/3287

BAYNE, B.L. and WORRALL, C.M., 1980. Growth and production of mussels Mytilus edulis from two populations. Marine Ecology Progress Series, vol. 3, pp. 317-328. http://dx.doi.org/10.3354/ meps003317.

BERGONCI, P.E.A. and THOME, J.W., 2008. Vertical distribution, segregation by size and recruitment of the yellow clam Mesodesma mactroides Deshayes, 1854 (Mollusca, Bivalvia, Mesodesmatidae) in exposed sandy beaches of the Rio Grande do Sul state, Brazil. Brazilian Journal of Biology = Revista Brasileira de Biologia, vol.68, no. 2, pp. 297-305. http://dx.doi.org/10.1590/ S1519-69842008000200010. PMid:18660957.

CANESI, L. and FABBRI, E., 2015. Environmental effects of BPA: focus on aquatic species. Dose-Response, vol. 13, no. 3, pp. 1-14. http://dx.doi.org/10.1177/1559325815598304. PMid:26674307. 
CAPPEZANI, D.A.A. and OLIVIER, S.R. and PENCHASZADEH, P.E., 1971. Dinamica de población. In: S.R. OLIVIER, ed. Estructura de la comunidad, dinamica de población y biologia de la almeja amarilla (Mesodesma mactroides, Desh. 1854) en Mar Azul. Argentina: Instituto de Biología Marina, Chap. 3, pp. 49-64.

CARVALHO, Y.B.M., ROMANO, L.A. and POERSCH, L.H.S., 2015. Effect of low salinity on the yellow clam Mesodesma mactroides. Brazilian Journal of Biology = Revista Brasileira de Biologia, vol. 75, no. 1, pp. 8-12. http://dx.doi.org/10.1590/1519-6984.03213.PMid:25945615.

CLEDÓN, M. and NUÑEZ, J.D., 2010. Siphon nipping facilitates lethal predation in the clam Mesodesma mactroides (Reeve, 1854) (Mollusca: bivalva). Marine Biology, vol. 157, no. 4, pp. 737-745. http://dx.doi.org/10.1007/s00227-009-1357-0.

COSCARÓN, S., 1959. La almeja amarilla (Mesodesma mactroides, Deshayes) de la costa de la Provincia de Buenos Aires. Agro Publ Tec, vol. 1, no. 3, pp. 1-66.

DEFEO, O. and SCARABINO, V., 1990. Ecological significance of a possible deposit-feeding strategy in Mesodesma mactroides (Deshayes, 1854) (Mollusca: pelecypoda). Atlântica, vol. 12, pp. 55-65.

DEFEO, O., REY, M. and CASCUDO, J., 1989. Estimaciones de stock del recurso almeja amarilla (Mesodesma mactroides) en base al analisis de cohortes (POPE, 1972). Publicaciones de la Comisión Técnica Mixta del Frente Marítimo, vol. 4, pp. 41-54.

FERRERI, G.B., 2014. Length-weight relationships and condition factors of the Humboldt squid (Dosidicus gigas) from the Gulf of California and the Pacific Ocean. Journal of Shellfish Research, vol. 33, no. 3, pp. 769-780. http://dx.doi. org/10.2983/035.033.0311.

FOOD AND AGRICULTURE ORGANIZATION OF THE UNITED NATIONS - FAO, 2020. The state of world fisheries and aquaculture. Rome: FAO, $224 \mathrm{p}$.

FROESE, R., 2006. Cube law, condition factor and weight--length relationships: history, meta-analysis and recommendations. Journal of Applied Ichthyology, vol. 22, no. 4, pp. 241-253. http:// dx.doi.org/10.1111/j.1439-0426.2006.00805.x.

GOSLING, E., 2015. Reproduction, settlement and recruitment. In: E. GOSLING, ed. Marine bivalve molluscs. Oxford: John Wiley \& Sons, Chap. 5, pp. 157-202. http://dx.doi. org/10.1002/9781119045212.ch5.

HARTMANN, J.T., BEGGEL, S., AUERSWALD, K. and GEIST, J., 2016. Determination of the most suitable adhesive for tagging freshwater mussels and its use in an experimental study of filtration behaviour and biological rhythm. The Journal of Molluscan Studies, vol. 82, no. 3, pp. 415-421. http://dx.doi. org/10.1093/mollus/eyw003.

HELM, M.M., BOURNE, N. and LOVATELLI, A., 2004. Hatchery culture of bivalves: a practical manual. Rome: FAO, 177 p. FAO Fisheries Technical Paper, no. 471.

HERRMANN, M., ALFAYA, J.E.F., LEPORE, M.L., PENCHASZADEH, P.E. and LAUDIEN, J., 2009. Reproductive cycle and gonad development of the Northern Argentinian Mesodesma mactroides (Bivalvia: mesodesmatidae). Helgoland Marine Research, vol. 63, no. 3, pp. 207-218. http://dx.doi.org/10.1007/s10152-009-0150-2.

KUMAR, S.A., NADEEKA, G.G. and JAYASENA, D.D., 2018. Comparative analysis of morphological characteristics of clam (Marcia opima) in Mannar coastal belt, Sri Lanka. International Journal of Fisheries and Aquatic Studies, vol. 6, no. 3, pp. 392-399.

LEMARIÉ, D.P., SMITH, D.R., VILLELA, R.F. and WELLER, D.A., 2000. Evaluation of tag types and adhesives for marking freshwater mussels (Mollusca: unionidae). Journal of Shellfish Research, vol. 19, pp. 247-250.

MASELLO, A., 1987. Consideraciones sobre crecimiento y biologia reproductiva de la almeja amarilla Mesodesma mactroides
(Deshayes, 1854). Uruguay: Facultad de Humanidades y Ciencias, Universidad de la Republica, 126 p. Tesis in Licenciatura en Oceanografia Biologica.

MCLACHLAN, A., 2018. Fisheries. In: A. MCLACHLAN and O. DEFEO, eds. The ecology of sandy shores. 3rd ed. Cambridge: Academic Press, pp. 331-372. http://dx.doi.org/10.1016/B978-0-12809467-9.00014-X.

PROVERBIO, C., CARNEVIA, D., JORGE-ROMERO, G. and LERCARI, D., 2019. Herramientas para el mantenimiento de la almeja amarilla Mesodesma mactroides en condiciones experimentales de cautiverio. Revista Laboratorio Tecnológico del Uruguay, vol. 18, pp. 124-141. http://dx.doi.org/10.26461/18.02.

SANTOS, J.J.S., BERNARDES, J.P., RAMÍREZ, J.R.B., RAMOS, C.O., GOMES, C.H.A.M. and ROMANO, L.A., 2020. Embryo and larval development of the yellow clam Mesodesma mactroides (Reeve, 1854) (Mesodesmatidae) in laboratory. Annals of the Brazilian Academy of Science, vol. 92, suppl. 1, pp. e20190053. http:// dx.doi.org/10.1590/0001-3765202020190053. PMid:32348413.

SANTOS, J.J.S., CARVALHO, Y.B., LOPES, D.A. and ROMANO, L.A., 2016. Immunological profile of the yellow clam Mesodesma mactroides (Mesodesmatidae) from the southern coast of Rio Grande do Sul, Brazil. Journal of Aquatic Animal Health, vol. 28, no. 1, pp. 11-20. http://dx.doi.org/10.1080/08997659.2015.111 6471. PMid:26913557.

SASSA, S., WATABE, Y., YANG, S. and KUWAE, T., 2011. Burrowing criteria and burrowing mode adjustment in bivalves to varying geoenvironmental conditions in intertidal flats and beaches. PLoS One, vol. 6, no. 9, pp. e25041. http://dx.doi.org/10.1371/ journal.pone.0025041. PMid:21957474.

SHARMA, R., VENKATESHVARAN, K. and PURUSHOTHAMA, C.S., 2005. Length-weight relationship and condition factor of Perna viridis (Linnaeus, 1758) and Meretrix (Linnaeus, 1758) from Mumbai waters. Journal of Indian Fisheries Association, vol. 32, pp. 157-163.

SIMAS, M.M., 2013. Bisfenol A desregula o sistema antioxidante, induzindo dano lipídico em juvenis de Mesodesma mactroides (Bivalvia: Mactracea). Rio Grande: Universidade Federal do Rio Grande, 48 p. Dissertação de Mestrado em Fisiologia Animal Comparada.

SKILLETER, G.A. and PETERSON, C.H., 1994. Control of foraging behaviour of individuals within an ecosystem context: the clam Macoma balthica and interactions between competition and siphon cropping. Oecologia, vol. 100, no. 3, pp. 268-278. http:// dx.doi.org/10.1007/BF00316954. PMid:28307010.

SOUSA, R., DELGADO, J., PINTO, A.R. and HENRIQUES, P., 2017. Growth and reproduction on the North-eastern Atlantic keystone species Patella aspera (Mollusca: patellogastropoda). Helgoland Marine Research, vol. 71, no. 8, pp. 1-13. http://dx.doi. org/10.1186/s10152-017-0488-9.

SPENCER, B.E., EDWARDS, D.B. and MILLICAN, P.F., 1991. Cultivation of Manila clams. Conway, UK: Ministry of Agriculture, Fisheries and Food Directorate of Fisheries Research, 29 p. Laboratory Leaflet, no. 65.

UNITED NATIONS EDUCATIONAL SCIENTIFIC AND CULTURAL ORGANIZATION - UNESCO, 1983. Chemical methods for use in marine environmental monitoring. Paris: Intergovernmental Oceanographic Commission, 53 p.

UTTING, S.D. and MILLICAN, P.F., 1997. Techniques for the hatchery conditioning of bivalve broodstocks and the subsequent effect on egg quality and larval viability. Aquaculture, vol. 155, no. $1-4$, pp. 45-54. http://dx.doi.org/10.1016/S00448486(97)00108-7. 
VAZQUEZ, N., FIORI, S., ARZUL, I., CARCEDO, C. and CREMONTE, F., 2016. Mass mortalities affecting populations of the yellow clam Amarilladesma mactroides along its geographic range. Journal of Shellfish Research, vol. 35, no. 4, pp. 739-745. http://dx.doi. org/10.2983/035.035.0403.
WISJMAN, J., TROOST, K., FANG, J. and RONCARATI, A. 2019. Global production of marine bivalves, trends and challenges. In: A. C. SMAAL. J. G. FERREIRA, J. GRANT, J. K. PETERSEN and O. STRAND, eds. Goods and services of marine bivalves. Cham: Springer, pp. 7-26. 